\title{
Effect of seaweed saps on growth, yield, nutrient uptake and economic im- provement of maize (sweet corn)
}

\author{
Ashok Pal*, Sanjay Kumar Dwivedi, Pradip Kumar Maurya, Poolchand Kanwar \\ Department of Agronomy, Indira Gandhi Krishi Vishwavidyalaya, Raipur- 492012 (Chhattisgarh), INDIA \\ *Correspondence author. E-mail: ashokpal.22@rediffmail.com \\ Received: April 4, 2015; Revised received: September 23, 2015; Accepted: November 26, 2015
}

\begin{abstract}
A field experiment was conducted during the rabi season of 2012-13 at Research cum Instructional Farm of Indira Gandhi Krishi Vishwavidyalaya, Raipur (Chhattisgarh) to study the effects of seaweed saps on growth, yield, nutrient uptake and economic of maize (sweet corn) in Matasi soil of Chhattisgarh. The foliar spray of two different species (namely Kappaphycus and Gracilaria) was applied thrice at different interval of crop with different concentrations $(0,2.5,5.0,7.5,10.0$ and $15 \% \mathrm{v} / \mathrm{v})$ of seaweed extracts. Foliar applications of seaweed extract significantly enhanced the growth, yield, nutrient uptake and B:C ratio parameters. The green cob yield $\left(189.97 \mathrm{q} \mathrm{ha}^{-1}\right)$ and fodder yield (345.19 q ha ${ }^{-1}$ ) were recorded highest under treatment $\left(T_{8}\right)$ 15\% G Sap + recommended dose of fertilizer (RDF) which was significant similar with treatment $15 \% \mathrm{~K} \mathrm{Sap}^{-\mathrm{RDF}}\left(185.24 \mathrm{q} \mathrm{ha}^{-1}\right)$ in case of green cob yield. The highest N, P and K uptake by green cob and fodder were observed under 15\% G Sap + RDF $\left(T_{8}\right)$. Treatment $15 \%$ G Sap + RDF $\left(T_{8}\right)$, recorded maximum gross return (Rs. 2,07,230 ha ${ }^{-1}$ ), net return (Rs. 1,38,756 ha ${ }^{-1}$ ) and $\mathrm{B}: \mathrm{C}$ ratio (2.0), which was followed by treatment $15 \% \mathrm{~K}$ Sap + RDF $\left(\mathrm{T}_{4}\right)$ with net return (Rs. 1,33,199 ha ${ }^{-1}$ ) and $\mathrm{B}: \mathrm{C}$ ratio (1.95). Treatment 15\% G Sap + RDF ( $\left.T_{8}\right)$ gave Rs. 45,996 ha ${ }^{-1}$ more as compared to Water spray + RDF $\left(T_{9}\right)$.
\end{abstract}

Keywords: Gracilaria, Kappaphycus, Maize cob yield, Nutrient uptake, Seaweed saps

\section{INTRODUCTION}

Sea weeds are marine algae, saltwater dwelling, and simple organisms that fall into the rather outdated general category of "plants". Most of them are the red (6000 species), brown (2000 species) or green (1200 species). A wide range of beneficial effects have been reported from the use of liquid seaweed extracts (Blunden, 1991), including increased crop yields, resistance of plants to frost, increased uptake of inorganic constituents from the soil, more resistance to stress conditions and reduction in storage losses of fruit. Sea weeds have proved effective in enhancing yield, pest and frost resistance in vegetables, fruits, flowers, cereals and pulses. Seaweed extracts had beneficial effect on seed germination and plant growth (Thirumal et al., 2003).

Maize (Zea mays L.) is a miracle crop emerging as the third most important cereal crop next to rice and wheat. It is grown for food, feed and as a source for numerous industrial products. Its array of diversity of uses and large hidden potential for exploitation led the renowned Nobel laureate, Norman E Borlaug to say that "last two decades saw the revolution in rice and wheat; the next few decades will become the maize era". India is the seventh largest producer of maize in an area of 8.11 million hectares with a production of 18.9 million tones and $2335 \mathrm{~kg} \mathrm{ha}^{-1}$ productivity (CMIE, 2010).
Sweet corn is one type of maize and contains 13 to $15 \%$ sugar in immature grains. Sweet corn is consumed at the soft dough stage with succulent grains, emerges as an alternative dish of urbanites namely, vegetable, roasted ears, soups, corn syrup and sweeteners etc. It also found a special niche in the preparation of native beer. Sweet corn can be harvested within 80 to 90 days after sowing. They are harvested earlier by 35 to 45 days compared to normal grain corn. Presently, greater emphasis is given to the cultivation of sweet corn due to increasing demand. There is an increasing tendency to produce sweet corn at commercial level to augment the income of the farming community dwelling in the outskirts of big cities and metropolis. Since there is limited scope to increase the area under sweet corn cultivation because of competition from other cereals and cash crops, the only alternative is through enhancement of productivity by various management factors (Bhatt, 2012). Therefore, to evaluate foliar application of different sea weeds sap to enhance growth, yield and nutrient uptake of Sweet corn with this objective trial was conducted towards the balancing nutrients requirement for the optimum productivity of maize (Sweet corn) crop.

\section{MATERIALS AND METHODS}

Experimental field and soil information: Field experiments were carried out during Rabi season of 2012 -13 at Research cum Instructional Farm of Indira Gan- 
dhi Krishi Vishwavidyalaya, Raipur (Chhattisgarh). The experimental site, Raipur comes under the seventh agro climatic region of India i.e. Eastern plateau and hills which is termed as sub humid with hot summer and cold winter. Weekly average meteorological data during the span of experimentation, recorded at meteorological observatory, Indira Gandhi Krishi Vishwavidyalaya, Raipur, for the year 2012-13. The total rainfall of $14.00 \mathrm{~mm}$ was received during rabi season 2012-13. The maximum temperature ranged in crop seasons was $25.60 \mathrm{C}$ to $30.70 \mathrm{C}$ during rabi season 2012-13. The minimum temperatures during the same season was $8.30 \mathrm{C}$ to $18.10 \mathrm{C}$. The Sun shine hours ranged from 3.3 to 9.9 hour day $^{-1}$. The other weather parameters were normal during the season. The experiment comprised of ten treatments, the details of treatments are T1: $2.5 \% \mathrm{~K} \mathrm{Sap}+\mathrm{RDF}, \mathrm{T} 2: 5.0 \% \mathrm{~K} \mathrm{Sap}+$ RDF, T3: 10\% K Sap + RDF, T4: 15\% K Sap + RDF, T5: 2.5\% G Sap + RDF, T6: 5.0\% G Sap + RDF, T7: 10\% G Sap + RDF, T8: 15\% G Sap + RDF, T9: Water Spray + RDF and T10: $7.5 \%$ K SAP+50\% RDF. Three sprays of Kappaphycus and Gracilaria extract were applied at different growth stages after 30, 50 and 70 day after sowing (DAS). The soil of experiment field was 'Inceptisols' (sandy loam) which is locally known as 'Matasi'. The soil of the site is sandy loam with $\mathrm{pH} 7.0$, EC $0.29 \mathrm{dSm}^{-1}$, organic carbon $0.60 \%$, Available N $269.69 \mathrm{~kg} \mathrm{ha}^{-1}$, P $14.42 \mathrm{~kg} \mathrm{ha}^{-1}$ and K $489.44 \mathrm{~kg} \mathrm{ha}^{-1}$. Spraying of sea weed sap was done in the field as per the treatment. First spraying was done at 30 DAS on February 15, 2012, second at 50 DAS on March 07, 2013 and third spray was done at 70 DAS on March 27, 2013 through knapsack sprayer. 500 liter ha water was used at 30 DAS and 600 liter at 50 and 70 DAS. The treatments were distributed in a randomized block design with three replications. The recommended dose of fertilizer $\mathrm{N}: \mathrm{P}_{2} \mathrm{O}_{5}: \mathrm{K}_{2} \mathrm{O}$ was 120 : 60: $40 \mathrm{~kg} \mathrm{ha}^{-1}$, respectively and $\mathrm{N}$ applied in the form of urea, $\mathrm{P}_{2} \mathrm{O}_{5}$ (Phosphorus) in the form of SSP and $\mathrm{K}_{2} \mathrm{O}$ (Potassium) in the form of muriate of potash (MOP). Entire phosphorus and potash were applied as basal. Nitrogen fertilizer was applied in three split's as per schedule that is, $50 \% \mathrm{~N}$ as basal and remaining in two equally split doses.

Observation taken: Growth attributing characters plant height $(\mathrm{cm})$, number of leaves; stem girth and yield attributing characters were recorded as per the standard method. The plant height $(\mathrm{cm})$, number of leaves and stem girth of maize was recorded at harvest. Five plants were used for recording observation. Mean value was then computed by dividing the summation with five. The post harvest observations like cob length, cob girth and cob weight were recorded from five tagged plants in each plot. After recorded data the average was worked out to get plants ${ }^{-1}$. The number of row $\operatorname{cob}^{-1}$ and number of grain row ${ }^{-1}$ were counted randomly selected five cobs from each plot. The mean value was calculated. The grain number per cob was worked out by using the formula, Grain number per cob $=$ No. of row X No. of grain row ${ }^{-1}$.

Plant analysis: Plant samples were drawn from the randomly tagged plants of different rows of the treated plots and analyzed. Nitrogen content in sweet corn plant at harvest was estimated. Phosphorus and potassium content were determined in the extracts after digesting the plant material with tri acid mixture of 9: 4: 1 (HNO3: H2SO4: HClO4). The analysis was done by micro Kjeldahl, Vanadomolybdophosphoric yellow colour and flame photometric methods for nitrogen, phosphorus and potassium, respectively. The uptake of N, P and $\mathrm{K}$ by sweet corn crop was computed on the basis of dry matter accumulation and expressed as $\mathrm{kg}$ ha $^{-1}$.

Statistical analysis: The experiment was laid out in randomized block design (RBD). The data obtained from various characters under study were analyzed by the method of analysis of variance as described by Gomez and Gomez (1984). The level of significance used in "F" test was given at 5 percent. Critical difference $(\mathrm{CD})$ values are given in the table at 5 percent level of significance, wherever the ' $F$ ' test was significant at 5 percent level.

Preparation and chemical composition of liquid sea weed extract: The seaweed extract used in this study was obtained from Kappaphycus sp. and Gracilaria sp. The algae were handpicked from the coastal area of Rameswaram, T. N., India during September, 2011. It was washed with seawater to remove unwanted impurities and transported to the field station at Mandapum, Rameswaram. Here, samples were thoroughly washed using tap water. After that, fresh seaweed samples were homogenized by grinder with stainless steel blades at ambient temperature, filtered and stored (Eswaran et al., 2005). The liquid filtrate was taken as $100 \%$ concentration of the seaweed extract and further diluted as per the treatments. The nitrogen $(\mathrm{N})$ content of seaweed extract $(100 \%$ concentrate) was determined by taking $20 \mathrm{ml}$ of filtrate which was oxidized and decomposed by concentrate sulphuric acid $(10 \mathrm{ml})$ with digestion mixture $(\mathrm{K} 2 \mathrm{SO} 4: \mathrm{CuSO} 4=5: 1)$ heated at $400^{\circ}$ $\mathrm{C}$ temperature for $2 \frac{1}{2}$ hours as described in the semimicro Kjeldahl method (AOAC, 1995), and other nutrient elements were analyzed by inductively coupled plasma-optical emission spectroscopy (ICP-OES), after wet digestion of filtrate $(20 \mathrm{ml})$ with $\mathrm{HNO} 3-\mathrm{HClO} 4$ (10:4) di-acid mixture $(20 \mathrm{ml})$ and heated at $100^{\circ} \mathrm{C}$ for 1 hour and then raise the temperature to about $150^{\circ} \mathrm{C}$ (Richards, 1954)

\section{RESULTS AND DISCUSSION}

Growth characters of maize (sweet corn): From the observations recorded at harvest (Table 3 ), it is revealed that the maximum plant height $(210.67 \mathrm{~cm})$ was recorded with application of $15 \%$ G Sap + RDF (T8) which was found at par with treatments T3, T4 and T7. The observation recorded for number of leaves plant ${ }^{-1}$ 
Table 1. Chemical composition of Kappaphycus sap.

\begin{tabular}{llll}
\hline Nutrient & Amount present & Nutrient & Amount present \\
\hline Moisture & $94.38 \mathrm{~g} / 100 \mathrm{ml}$ & Iron & $8.58 \mathrm{mg} / 100 \mathrm{ml}$ \\
Protein & $0.085 \mathrm{~g} / 100 \mathrm{ml}$ & Manganese & $0.22 \mathrm{mg} / 100 \mathrm{ml}$ \\
Fat & $0.0024 \mathrm{~g} / 100 \mathrm{ml}$ & Nickel & $0.35 \mathrm{mg} / 100 \mathrm{ml}$ \\
Crude fibre & $0.01 \mathrm{~g} / 100 \mathrm{ml}$ & Copper & $0.077 \mathrm{mg} / 100 \mathrm{ml}$ \\
Carbohydrate & $1.800 \mathrm{~g} / 100 \mathrm{ml}$ & Zinc & $0.474 \mathrm{mg} / 100 \mathrm{ml}$ \\
Energy & $7.54 \mathrm{Kcal} / 100 \mathrm{ml}$ & Chromium & $3.50 \mathrm{mg} / 100 \mathrm{ml}$ \\
Sodium & $18.10 \mathrm{mg} / 100 \mathrm{ml}$ & Lead & $0.51 \mathrm{mg} / 100 \mathrm{ml}$ \\
Potassium & $358.35 \mathrm{mg} / 100 \mathrm{ml}$ & Thiamine & $0.023 \mathrm{mg} / 100 \mathrm{ml}$ \\
Magnesium & $116.79 \mathrm{mg} / 100 \mathrm{ml}$ & Riboflavin & $0.010 \mathrm{mg} / 100 \mathrm{ml}$ \\
Phosphorous & $2.96 \mathrm{mg} / 100 \mathrm{ml}$ & B-Carotene & $0.0 \mathrm{mg} / 100 \mathrm{ml}$ \\
Calcium & $32.49 \mathrm{mg} / 100 \mathrm{ml}$ & Iodine & $160 \mathrm{mg} / 100 \mathrm{ml}$ \\
Indole acetic acid & $23.36 \mathrm{mg} / \mathrm{L}$ & Kinetin + Zeatin & $31.91 \mathrm{mg} / \mathrm{L}$ \\
Gibberelin GA & $27.87 \mathrm{mg} / \mathrm{L}$ & &
\end{tabular}

Data courtesy: National Institute of Nutrition, Hyderabad, India (except growth hormone data generated by CSMCRI using quantitative MS-MS and LC-MS techniques)

Table 2. Chemical composition of Gracilaria sap.

\begin{tabular}{llll}
\hline \multicolumn{1}{c}{ Nutrient } & Amount present & Nutrient & Amount present \\
\hline Ash & $38.91 \mathrm{~g} / 100 \mathrm{~g}$ & Calcium & $295.50 \mathrm{mg} / 100 \mathrm{~g}$ \\
Crude protein & $9.58 \mathrm{~g} / 100 \mathrm{~g}$ & Copper & $0.20 \mathrm{mg} / 100 \mathrm{~g}$ \\
Crude fibre & $10.40 \mathrm{~g} / 100 \mathrm{~g}$ & Zinc & $1.00 \mathrm{mg} / 100 \mathrm{~g}$ \\
Crude lipid & $2.00 \mathrm{~g} / 100 \mathrm{~g}$ & Iron & $67.35 \mathrm{mg} / 100 \mathrm{~g}$ \\
Saturated fatty acid & $48.92 \%$ of total fatty acids & Manganese & $4.16 \mathrm{mg} / 100 \mathrm{~g}$ \\
Total amino acids & $889.78 \mathrm{mg} / \mathrm{g}$ of protein & Nickel & $0.92 \mathrm{mg} / 100 \mathrm{~g}$ \\
Moisture & $88.88 \%$ & Cobalt & $0.24 \mathrm{mg} / 100 \mathrm{~g}$ \\
Vitamin C & $28.50 \mathrm{mg} / 100 \mathrm{~g}$ & Sulphate & $106.20 \mathrm{mg} / 100 \mathrm{~g}$ \\
Carbohydrate & $45.92 \%$ & Chlorine & $1170.00 \mathrm{mg} / 100 \mathrm{~g}$ \\
Potassium & $8633.00 \mathrm{mg} / 100 \mathrm{~g}$ & Lead & $1.11 \mathrm{mg} / 100 \mathrm{~g}$ \\
Magnesium & $549.50 \mathrm{mg} / 100 \mathrm{~g}$ & Cadmium & $0.14 \mathrm{mg} / 100 \mathrm{~g}$ \\
Phosphorus & $278.50 \mathrm{mg} / 100 \mathrm{~g}$ & Sodium & $158.50 \mathrm{mg} / 100 \mathrm{~g}$ \\
\hline
\end{tabular}

Source: (Benjama and Masniyom, 2012). Gracilaria extract also contains variable amount of phytohormones like Auxin, Cytokinin, Abscisic acid etc. (Yokoya et al., 2010)

indicated that maximum numbers of leaves (12.40) was recorded under treatment $15 \% \mathrm{~K} \mathrm{Sap}+\mathrm{RDF}(\mathrm{T} 4)$ which was found at par with treatments T2, T3, T5, T6, T7 and T8. Data recorded for stem girth showed significant influence and spray of $15 \%$ G Sap + RDF (T8) produced the highest stem girth which was significantly similar in treatments T3, T4, T7 and T9. The lowest plant height, number of leaves and stems girth were recorded under treatment $7.5 \% \mathrm{~K} \mathrm{SAP}+50 \% \mathrm{RDF}$ (T10). The foliar spray of seaweed sap during important growth stages of sweet corn crop, increased their metabolism activity and act as growth stimulant for healthy plant

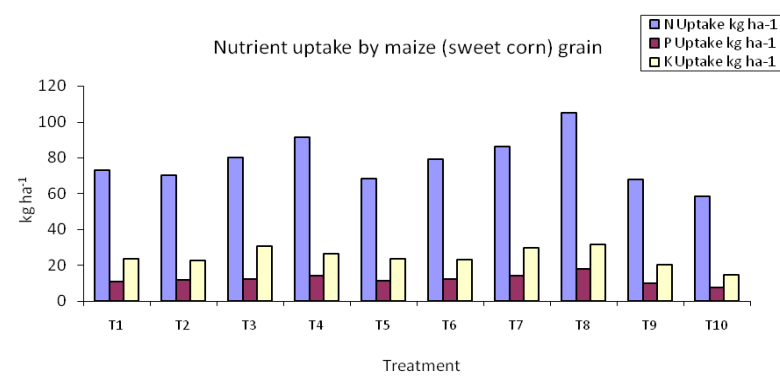

Fig. 1: Nutrient uptake $(N, P, K)$ by maize grain as influenced by seaweed saps. development. The increased growth and yield attributes may be due to the presence of some growth promoting substances such as IAA and IBA, gibberellins, cytokinins, micronutrients, vitamins and amino acids (Challen and Hemingway, 1966).

Yields attributes and yield of maize (sweet corn): The different sprays of seaweed sap were significantly influenced for yield attributes and yield except the observation recorded for cob length and cob girth (Table 4). The highest green cob weight with husk (374.08 $\left.\mathrm{g} \mathrm{cob}^{-1}\right)$, number of grains row $\operatorname{cob}^{-1}(17.47)$, number of grains row $^{-1}(39.87)$ and ultimately the high-

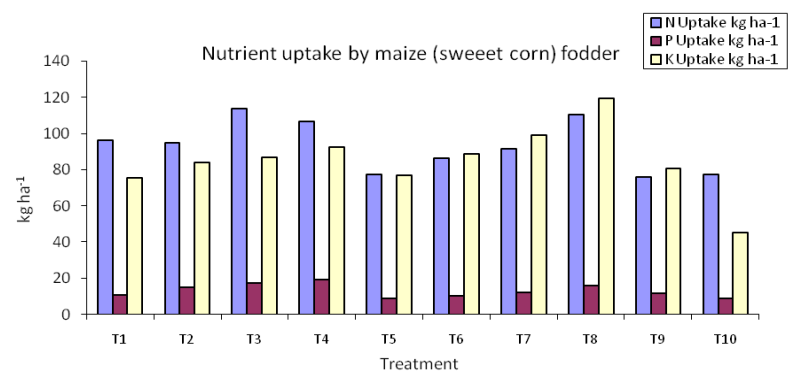

Fig. 2: Nutrient uptake (N, $P, K)$ by maize fodder as influenced by seaweed saps. 
Table 3. Growth characters of maize (Sweet corn) as influenced by seaweed saps.

\begin{tabular}{lccc}
\hline Treatment & $\begin{array}{c}\text { Plant height } \\
(\mathbf{c m})\end{array}$ & $\begin{array}{c}\text { No. of leaves } \\
\text { plant }^{-1}\end{array}$ & $\begin{array}{c}\text { Stem girth } \\
\text { (cm) }\end{array}$ \\
\hline $\mathrm{T}_{1}: 2.5 \%$ K Sap + RDF & 201.20 & 11.47 & 8.01 \\
$\mathrm{~T}_{2}: 5 \%$ K Sap + RDF & 204.80 & 12.07 & 8.23 \\
$\mathrm{~T}_{3}: 10 \%$ K Sap + RDF & 207.27 & 12.33 & 8.41 \\
$\mathrm{~T}_{4}: 15 \%$ K Sap + RDF & 209.53 & 12.40 & 8.53 \\
$\mathrm{~T}_{5}: 2.5 \%$ G Sap + RDF & 201.47 & 11.67 & 8.05 \\
$\mathrm{~T}_{6}: 5 \%$ G Sap + RDF & 204.60 & 11.80 & 8.25 \\
$\mathrm{~T}_{7}: 10 \%$ G Sap + RDF & 207.00 & 12.20 & 8.46 \\
$\mathrm{~T}_{8}: 15 \%$ G Sap + RDF & 210.67 & 12.33 & 8.67 \\
$\mathrm{~T}_{9}:$ Water Spray + RDF & 198.13 & 11.13 & 8.37 \\
$\mathrm{~T}_{10}: 7.5 \%$ K SAP+50\% RDF & 193.67 & 11.07 & 7.87 \\
$\mathrm{SEm} \pm$ & 1.50 & 0.25 & 0.10 \\
$\mathrm{CD}(\mathrm{P}=0.05)$ & 4.47 & 0.75 & 0.30 \\
\hline
\end{tabular}

Table 4. Yield attributes and yield of maize (sweet corn) as influenced by seaweed saps.

\begin{tabular}{|c|c|c|c|c|c|c|c|c|}
\hline Treatment & $\begin{array}{c}\text { Cob } \\
\text { length } \\
\text { with husk } \\
\text { (cm) }\end{array}$ & $\begin{array}{l}\text { Cob } \\
\text { girth } \\
\text { with } \\
\text { husk } \\
\text { (cm) }\end{array}$ & $\begin{array}{c}\text { Green } \\
\text { cob } \\
\text { weight } \\
\left(\text { g cob }^{-1}\right)\end{array}$ & $\begin{array}{c}\text { No of } \\
\text { grain } \\
\text { row cob } \text { cob }^{-1}\end{array}$ & $\begin{array}{c}\text { No. of } \\
\text { gain row } \\
1\end{array}$ & $\begin{array}{l}\text { Total } \\
\text { no. of } \\
\text { grain } \\
\text { cob }^{-1}\end{array}$ & $\begin{array}{c}\text { Green } \\
\text { cob yield } \\
\left(\mathbf{q} \mathbf{h a}^{-1}\right)\end{array}$ & $\begin{array}{c}\text { Fodder } \\
\text { yield } \\
\left(\mathrm{q} \mathrm{ha}^{-1}\right)\end{array}$ \\
\hline $\begin{array}{l}\text { T1: } 2.5 \% \text { K Sap + } \\
\text { RDF }\end{array}$ & 25.33 & 20.43 & 339.67 & 16.47 & 38.00 & 626.60 & 140.27 & 305.33 \\
\hline $\mathrm{T} 2: 5 \% \mathrm{~K}$ Sap + RDF & 27.09 & 20.87 & 350.00 & 16.60 & 38.87 & 646.60 & 145.61 & 314.08 \\
\hline $\begin{array}{l}\text { T3: 10\% K Sap + } \\
\text { RDF }\end{array}$ & 26.17 & 20.51 & 357.33 & 16.87 & 38.93 & 654.93 & 167.66 & 325.01 \\
\hline $\begin{array}{l}\text { T4: } 15 \% \text { K Sap + } \\
\text { RDF }\end{array}$ & 26.72 & 20.82 & 369.75 & 17.20 & 39.47 & 678.60 & 185.24 & 328.65 \\
\hline $\begin{array}{l}\text { T5: } 2.5 \% \text { G Sap + } \\
\text { RDF }\end{array}$ & 25.35 & 20.05 & 333.01 & 16.40 & 38.20 & 626.27 & 141.68 & 305.84 \\
\hline T6: 5\% G Sap + RDF & 26.47 & 20.57 & 349.49 & 16.87 & 38.87 & 655.40 & 152.92 & 312.82 \\
\hline $\begin{array}{l}\text { T7: } 10 \% \text { G Sap + } \\
\text { RDF }\end{array}$ & 26.59 & 20.67 & 359.85 & 17.13 & 39.27 & 672.20 & 167.97 & 326.40 \\
\hline $\begin{array}{l}\text { T8: } 15 \% \text { G Sap + } \\
\text { RDF }\end{array}$ & 26.98 & 20.78 & 374.08 & 17.47 & 39.87 & 695.80 & 189.97 & 345.19 \\
\hline $\begin{array}{l}\text { T9: Water Spray + } \\
\text { RDF }\end{array}$ & 26.27 & 19.79 & 340.30 & 16.40 & 38.20 & 627.00 & 138.29 & 305.87 \\
\hline $\begin{array}{l}\text { T10: } 7.5 \% \mathrm{~K} \\
\mathrm{SAP}+50 \% \mathrm{RDF}\end{array}$ & 25.77 & 19.72 & 332.83 & 15.80 & 37.20 & 588.67 & 111.09 & 286.13 \\
\hline $\mathrm{SEm} \pm$ & 0.45 & 0.28 & 8.36 & 0.24 & 0.47 & 12.04 & 4.30 & 4.16 \\
\hline $\mathrm{CD}(\mathrm{P}=0.05)$ & NS & NS & 24.86 & 0.73 & 1.41 & 35.78 & 12.79 & 12.38 \\
\hline
\end{tabular}

Table 5. Nutrient uptake by of maize (sweet corn) as influenced by seaweed saps.

\begin{tabular}{|c|c|c|c|c|c|}
\hline \multirow[b]{2}{*}{ Treatment } & \multirow{2}{*}{$\begin{array}{c}\text { Dry grain } \\
\text { yield } \\
\left(\mathbf{q} \mathbf{h a}^{-1}\right)\end{array}$} & \multirow{2}{*}{$\begin{array}{c}\text { Dry fodder } \\
\text { yield } \\
\left(\mathbf{q} \mathbf{h a}^{-1}\right)\end{array}$} & \multicolumn{3}{|c|}{ Total nutrient uptake } \\
\hline & & & $\begin{array}{r}\text { N uptake } \\
\left(\mathrm{kg} \mathrm{ha}^{-1}\right)\end{array}$ & $\begin{array}{c}\text { P uptake } \\
\left(\mathrm{kg} \mathrm{ha}^{-1}\right)\end{array}$ & $\begin{array}{r}\text { K uptake } \\
\left(\mathrm{kg} \mathrm{ha}^{-1}\right) \\
\end{array}$ \\
\hline $\mathrm{T} 1: 2.5 \% \mathrm{~K}$ Sap $+\mathrm{RDF}$ & 22.54 & 61.87 & 169.36 & 21.65 & 98.75 \\
\hline $\mathrm{T} 2: 5 \% \mathrm{~K}$ Sap + RDF & 22.02 & 68.56 & 165.07 & 26.76 & 106.33 \\
\hline T3: $10 \%$ K Sap + RDF & 25.52 & 74.92 & 193.63 & 29.38 & 117.21 \\
\hline T4: $15 \%$ K Sap + RDF & 27.47 & 82.52 & 197.72 & 33.57 & 118.46 \\
\hline T5: $2.5 \%$ G Sap + RDF & 22.07 & 57.43 & 145.63 & 20.40 & 100.31 \\
\hline T6: 5\% G Sap + RDF & 23.52 & 64.61 & 165.05 & 22.58 & 111.54 \\
\hline T7: $10 \%$ G Sap + RDF & 26.36 & 73.10 & 177.66 & 26.41 & 128.99 \\
\hline T8: $15 \%$ G Sap + RDF & 30.00 & 86.77 & 215.27 & 33.95 & 150.59 \\
\hline T9: Water Spray + RDF & 20.20 & 65.32 & 143.46 & 21.53 & 101.25 \\
\hline T10: $7.5 \% \mathrm{~K} \mathrm{SAP}+50 \% \mathrm{RDF}$ & 15.48 & 43.8 & 135.49 & 16.67 & 60.15 \\
\hline $\mathrm{SEm} \pm$ & 1.56 & 2.4 & 6.88 & 1.12 & 3.88 \\
\hline $\mathrm{CD}(\mathrm{P}=0.05)$ & 4.64 & 7.14 & 20.47 & 3.35 & 11.55 \\
\hline
\end{tabular}


Table 6. Cost of cultivation, gross return, net return and B:C ratio of maize (sweet corn) as influenced by seaweed saps.

\begin{tabular}{|c|c|c|c|c|c|c|c|c|}
\hline Treatment & $\begin{array}{c}\text { Cob } \\
\text { yield } \\
\left(\mathrm{q} \mathrm{ha}^{-1}\right)\end{array}$ & $\begin{array}{c}\text { Fodder } \\
\text { yield } \\
\left(\mathrm{q} \mathrm{ha}^{-1}\right)\end{array}$ & $\begin{array}{l}\text { Economic } \\
\text { Return } \\
\text { from Cob } \\
\left(\mathrm{Rs} \mathrm{ha}^{-1}\right)\end{array}$ & $\begin{array}{c}\text { Economic } \\
\text { Return } \\
\text { from Fod- } \\
\text { der } \\
\left(\mathrm{Rs} \mathrm{ha}^{-1}\right) \\
\end{array}$ & $\begin{array}{c}\text { Cost of } \\
\text { Cultiva- } \\
\text { tion } \\
\left(\mathrm{Rs} \mathrm{ha}^{-1}\right)\end{array}$ & $\begin{array}{c}\text { Gross } \\
\text { return } \\
\left(\mathrm{Rs} \mathrm{ha}^{-1}\right)\end{array}$ & $\begin{array}{c}\text { Net } \\
\text { return } \\
\text { (Rs ha- } \\
\text { 1) }\end{array}$ & $\begin{array}{l}\mathrm{B}: \mathrm{C} \\
\text { ration }\end{array}$ \\
\hline $\begin{array}{l}\text { T1: } 2.5 \% \text { K Sap }+ \\
\text { RDF }\end{array}$ & 140.27 & 305.33 & 140270 & 15267 & 62099 & 155537 & 93438 & 1.50 \\
\hline T2: $5 \%$ K Sap + RDF & 145.61 & 314.08 & 145610 & 15704 & 63374 & 161314 & 97940 & 1.55 \\
\hline T3: $10 \%$ K Sap + RDF & 167.66 & 325.01 & 167660 & 16251 & 65924 & 183911 & 117987 & 1.79 \\
\hline $\mathrm{T} 4: 15 \% \mathrm{~K} \mathrm{Sap}+\mathrm{RDF}$ & 185.24 & 328.65 & 185240 & 16433 & 68474 & 201673 & 133199 & 1.95 \\
\hline $\begin{array}{l}\text { T5: } 2.5 \% \text { G Sap + } \\
\text { RDF }\end{array}$ & 141.68 & 305.84 & 141680 & 15292 & 62099 & 156972 & 94873 & 1.53 \\
\hline T6: $5 \%$ G Sap + RDF & 152.92 & 312.82 & 152920 & 15641 & 63374 & 168561 & 105187 & 1.66 \\
\hline T7: $10 \%$ G Sap + RDF & 167.97 & 326.4 & 167970 & 16320 & 65924 & 184290 & 118366 & 1.80 \\
\hline T8: $15 \%$ G Sap + RDF & 189.97 & 345.19 & 189970 & 17260 & 68474 & 207230 & 138756 & 2.03 \\
\hline $\begin{array}{l}\text { T9: Water Spray + } \\
\text { RDF }\end{array}$ & 138.29 & 305.87 & 138290 & 15294 & 60824 & 153584 & 92760 & 1.53 \\
\hline $\begin{array}{l}\text { T10: } 7.5 \% \mathrm{~K} \\
\text { SAP+50\% RDF }\end{array}$ & 111.09 & 286.13 & 111090 & 14307 & 61590 & 125397 & 63807 & 1.04 \\
\hline
\end{tabular}

est number of grain $\operatorname{cob}^{-1}(695.80)$ were observed under treatment $15 \%$ G Sap + RDF (T8). However, treatment T2, T3, T4, T6 and T7 were found at par in case of green cob weight and number of grains row $^{-1}$. In case of number of grains row $\mathrm{cob}^{-1}$ treatments $\mathrm{T} 3, \mathrm{~T} 4$, T6 and T7 were found at par and in case of total number of grains $\mathrm{cob}^{-1}$ treatment $\mathrm{T} 4$ and $\mathrm{T} 7$ found at par with treatment $15 \% \mathrm{G}$ Sap $+\operatorname{RDF}\left(\mathrm{T}_{8}\right)$. Above all yield characters were observed lowest under treatment $7.5 \% \mathrm{~K} \mathrm{SAP}+50 \%$ RDF $\left(\mathrm{T}_{10}\right)$ due to minimum response of nutrient applied in the field under this treatment. Green cob yield (189.97 $\left.\mathrm{q} \mathrm{ha}^{-1}\right)$ and fodder yield $\left(345.19 \mathrm{q} \mathrm{ha}^{-1}\right)$ were recorded highest under treatment $15 \%$ G Sap + RDF $\left(\mathrm{T}_{8}\right)$ which was significantly similar with treatment $15 \% \mathrm{~K} \mathrm{Sap}+\mathrm{RDF}\left(\mathrm{T}_{4}\right)$ in case of green cob yield. The lowest green cob yield and fodder yield was recorded under treatment $7.5 \% \mathrm{~K} \mathrm{SAP}+50 \%$ RDF $\left(\mathrm{T}_{10}\right)$. Growth hormones like cytokinin and gibberellins have been detected in the extract of Kappaphycus alvarezii and Gracilaria spp. which might be responsible for beneficial effects in the present study. Significant increase in seed yield of black gram (Venkataraman and Mohan, 1997) and marketable bean by $24 \%$ has been reported with the foliar applicaion of seaweed extract (Temple and Bomke, 1989). Growth hormones like cytokinin and gibberellins along with other trace element have been detected in the extract of Kappaphycus spp. and Gracilaria spp. which might be responsible for beneficial effects in the present study. Foliar application of aqueous extract of gives positive result on the growth and yield of pea and black gram (Ramamoorthy et al., 2006a, 2006b, Ramamoorthy and Sujatha, 2007). Seaweed extracts not only increase the vegetative growth of the plant but it also triggers the early flowering, fruiting in crops and ultimately on grain yield. Zodape et al. (2011) also reported that foliar application of liquid extract of Kappaphycus spp. increase the yield tomato. Application of seaweed extract enhanced the early growth and yield attribute properties in legume plants and 12-25\% higher yield than that of control (Sethi and Adhikary, 2008).

Nutrient uptake by maize (sweet corn): Grain yield was recorded at harvest of the maize crop on dry basis till the natural senescence of crop, the grain yield $(30 \mathrm{q}$ $\left.\mathrm{ha}^{-1}\right)$ and fodder yield $\left(86.77 \mathrm{q} \mathrm{ha}^{-1}\right)$ were recorded highest under treatment $15 \%$ G Sap + RDF (T8) which was found at par with treatment T3, T4 and T7 in case grain yield and treatment $\mathrm{T} 4$ found at par in case of fodder yield with same treatment. The lowest grain yield (15.48 $\left.\mathrm{q} \mathrm{ha}^{-1}\right)$ and fodder yield (43.80 $\left.\mathrm{q} \mathrm{ha}^{-1}\right)$ were recorded under treatment $7.5 \% \mathrm{~K} \mathrm{SAP}+50 \%$ RDF (T10). The nutrient uptake was analyzed for grain (Fig. 1) and fodder (Fig. 2) after harvest of crop was done, the maximum $\mathrm{N}, \mathrm{P}$ and $\mathrm{K}$ uptake in grain was observed under treatment 15\% G Sap + RDF (T8) which was found at par with treatment $\mathrm{T} 4$ in case of $\mathrm{N}$ uptake in grain and treatments $\mathrm{T} 3$ and $\mathrm{T} 7$ were found at par in case of $\mathrm{K}$ uptake of grain. The lowest uptake of $\mathrm{N}, \mathrm{P}$ and $\mathrm{K}$ in grain was recorded under treatment $7.5 \% \mathrm{~K} \mathrm{SAP}+50 \% \mathrm{RDF}\left(\mathrm{T}_{10}\right)$. The data recorded for nutrient uptake in fodder, the maximum $\mathrm{N}$ uptake was recorded under treatment $10 \% \mathrm{~K}$ Sap $+\operatorname{RDF}\left(\mathrm{T}_{3}\right)$ which was found at par with treatments $T_{4}$ and $T_{8}$. The maximum $P$ uptake in fodder was recorded under treatment $15 \% \mathrm{~K}$ Sap $+\mathrm{RDF}\left(\mathrm{T}_{4}\right)$ and maximum $\mathrm{K}$ uptake was observed under treatment $15 \% \mathrm{G} \mathrm{Sap}+\mathrm{RDF}\left(\mathrm{T}_{8}\right)$. The lowest $\mathrm{P}$ and $\mathrm{K}$ uptake in fodder was recorded under treatment $7.5 \% \mathrm{~K} \mathrm{SAP}+50 \% \mathrm{RDF}\left(\mathrm{T}_{10}\right)$ and the lowest $\mathrm{N}$ uptake was recorded under treatment Water Spray + RDF $\left(\mathrm{T}_{9}\right)$. The total nutrient uptake by maize (Table 5), the maximum total N, P and $\mathrm{K}$ uptake were observed under $15 \% \mathrm{G}$ sap $+\mathrm{RDF}\left(\mathrm{T}_{8}\right)$ which was found at par with only treatment $10 \% \mathrm{~K}$ sap + RDF $\left(\mathrm{T}_{4}\right)$ for total $\mathrm{N}$ and $\mathrm{P}$ uptake. These results are closely similar with findings of Pramanick et. al. (2013) who 
noted that the foliar application of seaweed sap improved the nutrient uptake capacity of crop. Presence of marine bioactive substance in seaweed sap improves stomata uptake efficiency in treated plants compared to non treated ones (Mancuso et. al., 2006). The findings of Rathore et. al. (2009) also confirmed that the foliar application of $15 \%(\mathrm{v} / \mathrm{v})$ aqueous extracts prepared from fresh Kappaphycus alvarezii resulted in 57\% increase of Glycine max yield compare to the control and intensified nutrient uptake by soybean crop.

Economics of maize (sweet corn): It is revealed from the data present in table 6 , that the cost of cultivation of maize (sweet corn) varied from Rs. 60,824 to $68,474 \mathrm{ha}^{-1}$ owing to the use of different doses of seaweed sap and fertilizers. The data recorded for yield showed that the maximum cob yield (189.97 $\left.\mathrm{q} \mathrm{ha}^{-1}\right)$ was observed under treatment 15\% G Sap + RDF (T8), hence, as compared with other treatment it gave maximum gross return (Rs. 2,07,230 ha ${ }^{-1}$ ), net return (Rs. 1,38,756 ha ${ }^{-1}$ ) and $\mathrm{B}: \mathrm{C}$ ratio (2.0), which was followed by treatment $15 \%$ K Sap + RDF (T4) with net return (Rs. 1,33,199 ha-1) and B:C ratio (1.17). Treatment $15 \%$ G Sap + RDF (T8) gave Rs. 45,996 ha ${ }^{-1}$ more as compared to Water spray + RDF (T9). Application of seaweed extract enhanced the early growth and yield attribute properties in legume plants and yield return of $12-25 \%$ more than that of control (Sethi and Adhikary, 2008).

\section{Conclusion}

It was concluded that the seaweed extracts are effective in increasing the growth parameters, yield attributes of maize and its application gave the maximum return. The saps also enhance nutrient uptake by maize cob and fodder. Presence of some macro and micro-elements and plant growth regulators, especially cytokinins, IAA, GA in Kappaphycus and Gracilaria extracts is responsible for the increased yield and improved nutrition of sweet corn receiving foliar application of the aforesaid two saps.

\section{ACKNOWLEDGEMENTS}

The authors are thankful to Director, CSMCRI, Bhavnagar (Gujarat) for encouragement and providing necessary facilities and funds for the conducting this scientific study.

\section{REFERENCES}

AOAC (1995). Official methods of analysis of AOAC international. In: Cunniff, P. (Ed.), Contaminants, Drugs, 16th ed. Agricultural Chemicals, vol. 1. AOAC International, Wilson Boulevard, Virginia, USA.

Bhatt, S.P. (2012). Response of sweet corn hybrid to varying plant densities and nitrogen levels. African Journal of Agricultural Research, 7 (46): 6158-6166

Blunden, G. (1991). Seaweed Resources in Europe: Uses and Potential. John Wiley \& Sons, Chichester, 65-81.

Benjama, O. and Masniyom, P. (2012). Biochemical composi- tion and physicochemical properties of two red seaweeds (Gracilaria fisheri and G. tenuistipitata) from the Pattani Bay in Southern Thailand. J. Sci. Technol., 34(2):223-230.

Challen, S.B., and Hemingway, J.C. (1966). Growth of higher plants in response of feeding with seaweed extracts. Proc. Fifth Int. Seaweed Symp., 359-367.

CMIE (2010). Centre of Monitoring India Economy Pvt.Limited, Apple Apetile, Mumbai.

Eswaran, K., Ghosh, P.K., Siddhanta, A.K., Patolia, J.S., Periyasamy, C., Mehta, A.S., Mody, K.H., Ramavat, B.K., Prasad, K., Rajyaguru, M.R., Reddy, S.K.C.R., Pandya, J.B. and Tewari, A. (2005). Integrated method for production of carrageenan and liquid fertilizer from fresh seaweeds. United States Patent no. 6893479.

Gomez, K.A. and Gomez, A.A. (1984). Statistical procedures for Agricultural Research. A Willey- Interscience Publication, John Willey and Sons, New York.

Mancuso, S., Azzarello, E., Mugnai, S. and Briand, X. (2006). Marine bioactive substances (IPA extract) improve foliar ion uptake and water tolerance in potted Vitis vinifera plants. Adv. Horticul. Sci., 20:156-161.

Pramanick, B., Brahmachari, K. and Ghosh, A. (2013). Effect of seaweed saps on growth and yield improvement of greengram. African Journal of Agricultural Research, 8 (13): 1180-1186.

Rathore, S.S., Chaudhary, D.R., Boricha, G.N., Ghosh, A., Bhatt, B.P., Zodape, S.T. and Patolia, J.S. (2009). Effect of seaweed extract on the growth, yield and nutrient uptake of soybean. Botany, 75 (2): 351-355.

Ramamoorthy, K., Sujatha, K., Sivasubramaniam, K. and Subburamu, K. (2006a). Organic priming with Sargassum polycystum extracts on vigour and viability in cowpea Vigna unguiculata L. Seaweed Res. Utiln., 28: 85-88.

Ramamoorthy, K., Sujatha, K., Sivasubramaniam, K. and Subburamu, K. (2006b). Utilisation of seaweed extract for enhancing yield in black gram Vigna mungo L. Seaweed Res. Utiln., 29: 97-100.

Ramamoorthy, K. and Sujatha, K. (2007). Effect of seaweed extract on the ageing of black gram seeds. Seaweed Res. Utiln., 29: 119-123.

Richards, L.A. (1954). Diagnosis and Improvement of Saline Alkali Soils. USDA Handbook No. 60. USDA, W ashington, D.C.

Sethi, S.K. and Adhikary, S.P. (2008). Effect of seaweed liquid fertilizer on vegetative growth and yield of black gram, brinjal and tomato. Seaweed Res. Utiln., 30: 241-248.

Temple, W.D. and Bomke, A.A., (1989). Effects of Kelp (Macrocystis integrifolia and Ecklonia maxima) foliar applications on bean crop growth. Plant Soil, 117: 85-92.

Thirumal Thangam, R., S Maria Victorial Rani and M. Peter Marian (2003). Effect of seaweed liquid fertilizer on the growth and biochemical constituents of Cyamopsis tetragonoloba (L.) Taub. Seaweed Research and Utilisation, 25 (1\&2): 99-103.

Venkataraman, K. and Mohan, V.R. (1997). The effect of liquid seaweed fertilizer on black gram. Phykos., 36: 43-47.

Yokoya Nair, S., Stirk Wendy, A., Van Staden Johannes, Novak Ondrej, Tureckova Veronika, Pencik Ales, Strnad Miroslav (2010). Endogenous cytokinins, auxins, and abscisic acid in red algae from Brazil. J. Phycol., $6: 1198-1205$.

Zodape, S.T., Gupta, A., Bhandari, S.C., Rawat, U.S., Chaudhari, D.R., Eswaran, K. and Chikara, J. (2011). Foliar application of seaweed sap as bio-stimulant for enhancement of yield and quality of tomato. Journal of Scientific \& Industrial Research, 70: 215-219. 